\title{
EVALUATION OF RAIL TRAFFIC QUALITY IN POZNAŃ BY COMPUTER SIMULATION*
}

\author{
JEREMI RYCHLEWSKI \\ Institute of Civil Engineering, Poznań University of Technology \\ Piotrowo 5, 61-138 Poznań, Poland
}

(Rec. 14 November 2003)

\begin{abstract}
Presented in this paper are SOUT and FLEXSYT simulation models in use for rail traffic quality analysis. The SOUT model is a macro-model based on an idea of optimal intensity of traffic. Results of SOUT simulations for Poznañ Railway Knot show influence of traffic organisation on capacity, influence of high traffic intensity on traffic quality, and a need for peak periods' rail traffic investigations. Result of simulations done on the FLEXSYT micro-model show advantages and perils of intelligent traffic management. They include junctions with high intensity of traffic, tram priority, and coordination. A comparison and contrast between simulation results and practical implementations leads to conclusions about proper design process and high requirements of intelligent traffic management.
\end{abstract}

\section{INTRODUCTION}

Financial problems have always been a barrier in human mobility and freight transport development. The problems derived not only from high infrastructure costs, but also from economical and technical indivisibility of transportation network [11]. In other words not only must a bridge be built, but also it has to be connected to an existing road (technical indivisibility), and the bridge has to shorten some paths in the network to return its cost expenditures (economical indivisibility). Proper network design for new construction, as well as for optimal use of existing infrastructure, becomes therefore a very important part of transport improvement process.

Computational methods have become a major element of an infrastructure project evaluation. This is due to both low cost (in time and money) and simulation ability of computers. To show the problem of proper traffic quality evaluation an example of two station heads is given of Fig. 1. The left head consists of two elementary knots that can be aggregated to one, since there exists one point $\mathrm{X}$ through which all trains have to pass. Traffic quality on such knot can be with good precision calculated by deterministic methods, the advantage of computer simulation shows mainly in calculation time reduction. On the right head the primary knot (primary knot is a smallest knot eligible for traffic analysis [15]) consists of several elementary knots, which can be aggregated to two. This creates a situation in which a train not going through an elementary knot can be blocked by a collision occurring on that knot: for example train 1 scheduled to go from $c$ to $A$ has to wait for train 2 going from $A$ to $b$, blocking a train 3 sched-

\footnotetext{
* Dedicated to the memory of Professor Jacek Rychlewski
} 
uled from $B$ to $c$. The quality of train traffic depends therefore on probability of collision between trains 1 and 3 occurring at the same time as collision between
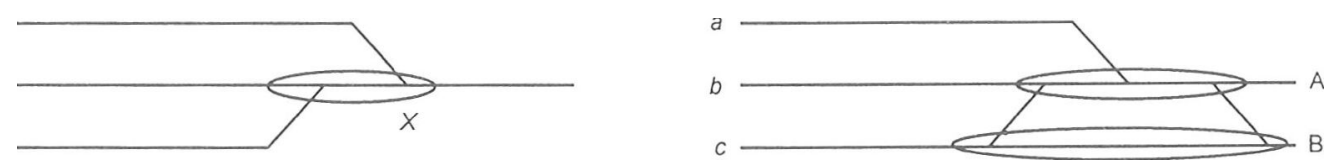

Fig. 1. Two station heads: first where the aggregated elementary and primary knots are identical, and second where the primary knot consists of two aggregated elementary knots

trains 1 and 2. Calculations done by students of Poznań University of Technology show, that use of deterministic methods gives results with error reaching 50\%. Computational methods are therefore necessary for proper evaluation of traffic quality on complex traffic knots.

\section{OPTIMAL INTENSITY OF RAIL TRAFFIC}

Construction and maintenance of a road requires some expenditures. However, since part of the cost does not depend on the amount of traffic, an increase of traffic causes a reduction in unit cost (cost per one road user). On the other hand, increase of traffic increases interactions between road users, causing a nonlinear rise in delay [12], therefore increasing unit cost of travel. These dependencies, shown of Fig. 2, create an optimum intensity of traffic, for which transport cost reaches minimum. The question was how to calculate the optimum intensity.

Friction between wheel and rail is small, therefore it takes a lot of time for a train to brake, and to gain speed. This causes both a significant delay if a train has to stop and a drop in track capacity. On that basis Wegierski [13] stated that "traffic is good when it is free" leading to a definition of optimal intensity as an intensity for which the traffic freedom, defined as number of trains passing freely through a knot, reaches maximum (Fig. 3). The optimal intensity is since 1994 a measure for practical rail traffic capacity on Polish National Railways.
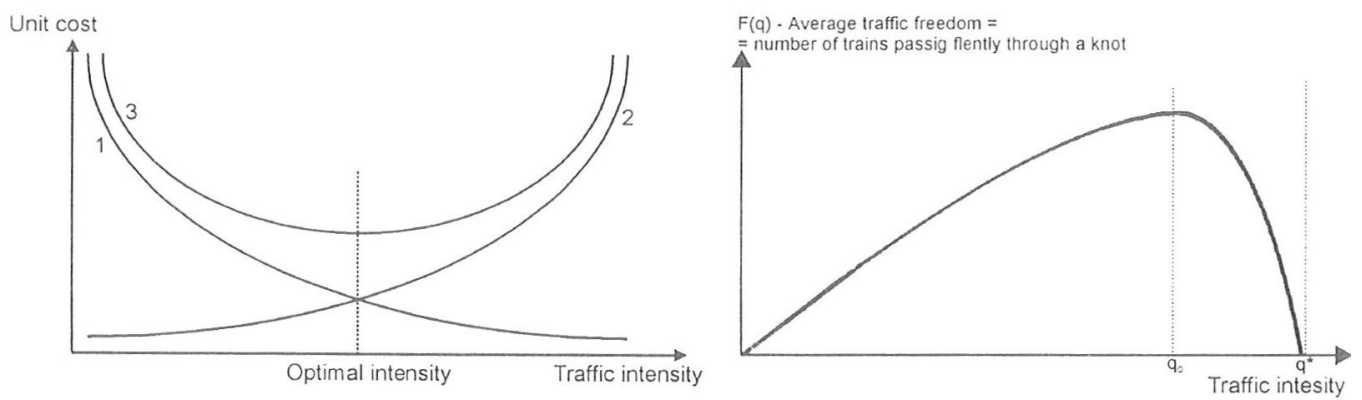

Fig. 2. Dependence of unit cost from traffic intensity 1 - unit cost of construction and maintenance 2 - unit cost of delay 3 - sum-

Fig. 3. Dependence of average traffic freedom on traffic intensity with a definition of optimal intensity $q_{0}$ and maximum intensity $q^{*}[14]$ 
On knots with high collision traffic (see chapter 4) the optimal intensity averages $60 \%$ of maximum intensity, therefore the knot can handle intensities higher than optimal. Delay, however, rises dramatically after reaching optimal intensity, so for trains with low priority this means a danger of long waiting times on that knot, unacceptable if the train has high punctuality requirements. Peak hour on station Poznań Wschód gives a good example of that dependence: according to the timetable each train scheduled to stop stops for only the time needed for exchange of passengers, however if a priority train is late, it disables other trains from entering Poznań Railway Diametric Line. These trains sometimes have to wait not only for that train to pass, but longer, since in the meantime other priority trains appear: on such basis the delay might reach 15 minutes. Calculations of capacity parameters for this station revealed that the peak hour intensity is but equal to optimal intensity [9].

Determination of the optimal intensity of a line can be made using some programs from the SOUT (System for Track Layout Evaluation) system. One of these programs is MW46, which simulates traffic conditions on a macro-model of a railway station head or a junction post. The model is being constructed on a basis of data concerning three "sheets": knot geometry (definition of routes by collision points and distance), incoming tracks (length of signal blocks), and traffic (route, speed, priority, stop time).

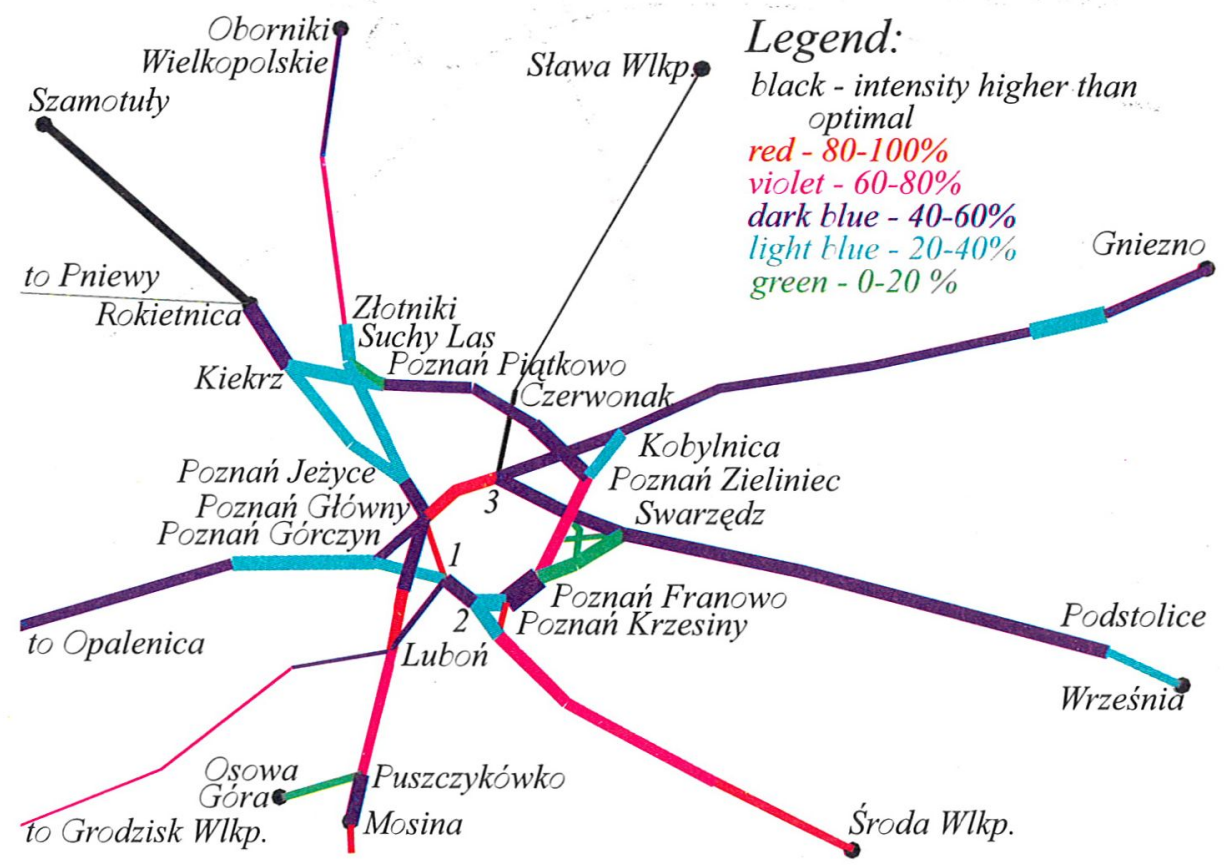

Fig. 4. Optimal intensity of rail traffic and rate of its utilisation on railway lines around Poznan. Line thickness if proportional to optimal intensity, colour utilisation rate [9] 
The program MW46 was used for calculating capacity parameters of railway lines around Poznań [9]. The results, presented on Fig. 4, show that the traffic intensity on these lines, in spite of visible rail traffic reduction in Poland, ranges between $2 \%$ and $90 \%$ of optimal intensity, on few lines at peak time exceeding optimal intensity. Due to this fact the railway net around Poznań turned out to be of low density, meaning that choice of route can be made on a basis of distance to be travelled; however if a track is being closed, the net may become a dense one, resulting in route choice depending on both the distance and delay caused by route collisions between trains [8].

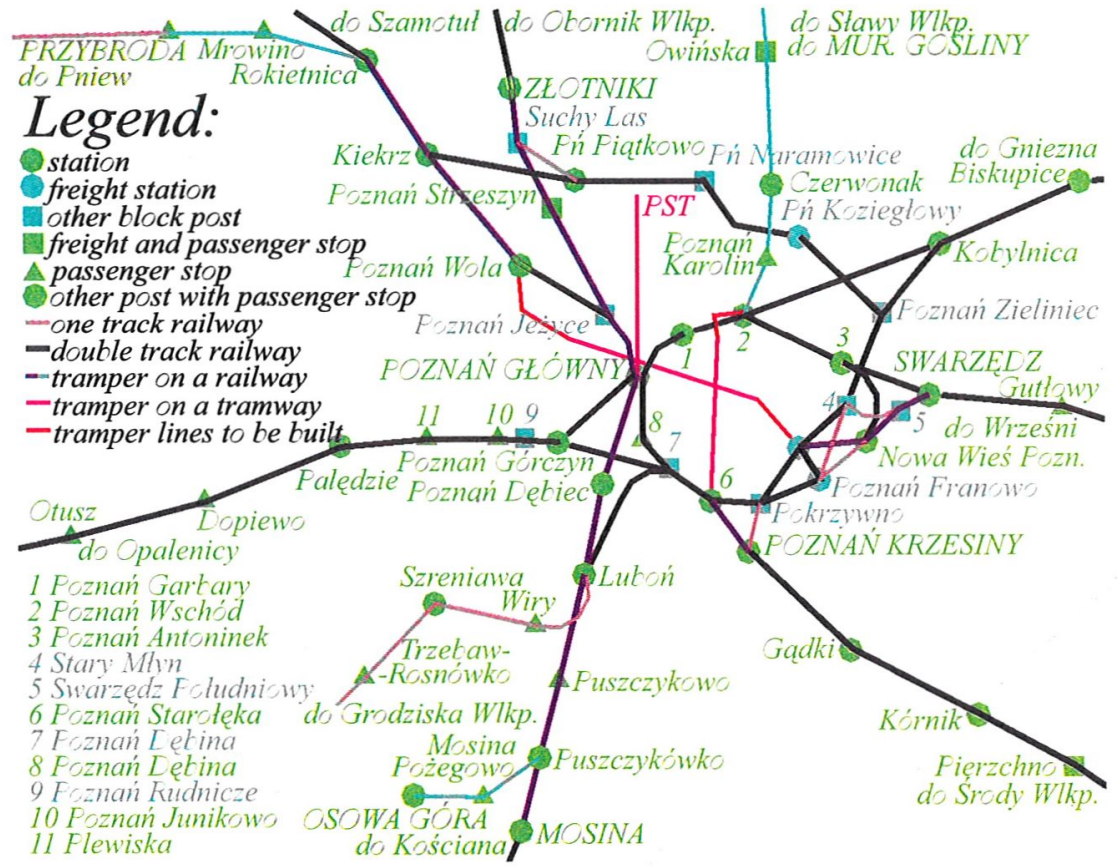

Fig. 5. A concept of using optimal intensity reserves for a tram - train system called "tramper". The combination of train and tram tracks allows to bypass railway "bottlenecks" in Poznań [5]

The capacity problems of selected tracks with high reserves of traffic optimal intensity on other lines was one of major arguments for a train - tram system in Poznań (called tramper). Figure 5 shows proposed layout of 4 tramper lines, allowing a bypass of "bottlenecks" (compare with Fig. 4) on Poznań Railway Diametric Line and near Poznań Jeżyce turnout, leaving however southern "bottleneck" for capacity increase through modernisation.

\section{LOW INTENSITY LINES}

The simulations of Poznań Railway Knot capacity parameters were done for 24 hour (standard period for railway traffic analysis), peak 6 hour and peak 1 hour periods. For local 
lines, however, the 1 hour simulations had to be skipped due to low capacity of these lines. The rail traffic reduction lead to operational cost cuts by closing some signal towers, resulting in capacity reduction. In the outcome travel time between two stations rose to 40 minutes, 60 minutes, and on some stretches even more. With 40 minutes headway two trains can enter the stretch in an hour, however the maximum intensity (maximum intensity is the last point on a function approaching the limit defined as capacity) is 36 trains per day, transforming into 1.5 trains per hour [9]. This example shows that the fractional values of optimal and maximum intensity should be approximated to the higher value.

\section{INFLUENCE OF TRACK COLLISIONS ON CAPACITY PARAMETERS}

Railway traffic between stations travels with speeds greater than driver's ability to stop the train if an obstacle occurs. Between two trains must therefore be at least one block signal, in practice the distance is seldom smaller than $1 \mathrm{~km}$. This means that on a stretch of railway without turnouts the minimum travel time usually constitutes a majority of an average travel time, therefore an average frequency of delay is relatively low. On railway junctions, however, a train might come from a separate track, making the probability of track significantly higher.

This dependence can be explained by equations presented below. According to Woch [16], optimal intensity $q_{0}$ can be calculated as:

$$
q_{0}=\frac{\mu}{1+(1-\mu \cdot \Delta)^{3}+2 \cdot \sqrt{(1-\mu \cdot \Delta)^{6}+(1-\mu \cdot \Delta)^{3}}}
$$

where:as $\mu$ - service intensity, $\Delta$ - minimal time between arrivals on collision place, calculated

$$
\Delta=\frac{1}{\mu}-\frac{1}{\mu^{\prime}}
$$

where: $\mu^{\prime}$ - expected value of service intensity random variable.

Defining $M$ as quotient of service intensity and its random variable (Eq. 3):

$$
1-\Delta \cdot \mu=\frac{\mu}{\mu^{\prime}}=M
$$

and substituting A in Eq. 1, Eq. 4 can be obtained [8]:

$$
q_{0}=\frac{\mu}{1+M^{3}+2 \cdot \sqrt{M^{6}+M^{3}}}
$$

$M=0$ describes an ideal situation where every object goes through the knot precisely at the time required, enabling the value of optimal intensity to reach capacity. In practice such order is impossible to reach, due to nonhomogeneity of traffic, human and technical factors, as well as coordination between neighbouring knots. A situation of full chaos $(M=1)$ is also 
impossible to obtain in real transport. Equation 4 shows however a drop of optimal intensity with increase of the service intensity random variable expected value The increase in the random value influence also lowers the capacity of such knot, but at a lower rate, as can be seen on Fig. 6. At this point it has to be stated that capacity is an asymptote of the number of trains that can pass through a knot in a time unit, and is lower (for $M=0$ equal) than the maximum number of trains that theoretically could pass through that knot.

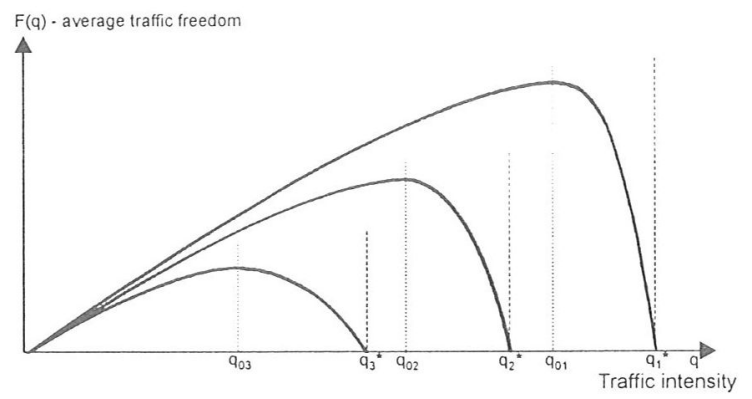

Fig. 6. Dependence of average traffic freedom on traffic intensity and track collisions [15]. Symbols: $q_{0}$ - track between stations; 2 - small track collisions; 3 typical station head

Table 1. Optimal intensity of Poznań main passenger station's outer heads [7, 9]

\begin{tabular}{lll}
\hline \multicolumn{1}{c}{ Organisation of traffic } & Northern head & Southern head \\
\hline year 2000; 24 hours & 539 trains/day & 270 trains/day \\
year 2000; peak 6 hours & 496 trains/day & not calculated \\
year 2000; peak 1 hour & 744 trains/day & not calculated \\
year 2003; peak 6 hours & 551 trains/day & 299 trains/day \\
year 2003; peak 6 hours + optimisation of track allocation & 605 trains/day & 319 trains/day \\
\hline
\end{tabular}

The dependence between track collisions and optimal intensity can be showed on an example of Poznań main passenger station's outer heads. Given in Table 1 are values of optimal intensity, the difference between them depending solely on track allocation. The track allocation differs due to minimisation of manoeuvres (allocating tracks for trains aimed at minimisation of the distance to storage track) on the station, if it does not influence train traffic quality. The high value of the peak 1 hour optimal intensity comes from absence of trains routed between Warsaw and Szczecin, therefore reducing the number of collisions.

\section{SIMULATIONS OF RAIL TRAFFIC BY FLEXSYT MICRO-MODEL}

FLEXSYT is a micro-model constructed for simulations of complex city junctions. The model is creating by declaring segments with homogeneous flow data (speed, capacity) connected respectively, with location of traffic lights, detectors, and public transport stops. Traffic is being modelled given its modal split with characteristics of each vehicle type, intensity and regularity of traffic produced by generators, direction of traffic flow on 
junctions, and time spent on public transport stops. The traffic light in the model can follow intelligent traffic management programs, including fully traffic responsive. An example of the segments (only tram and car) modelling Most Teatralny - Roosevelta - Dąbrowskiego junction in Poznań is presented on Fig. 7.

Fig. 7. Scheme of segments used for a FLEXSYT simulation of traffic quality on Most Teatralny Dąbrowskiego - Roosevelta junction in Poznań. Only car and tram segments are presented [1]

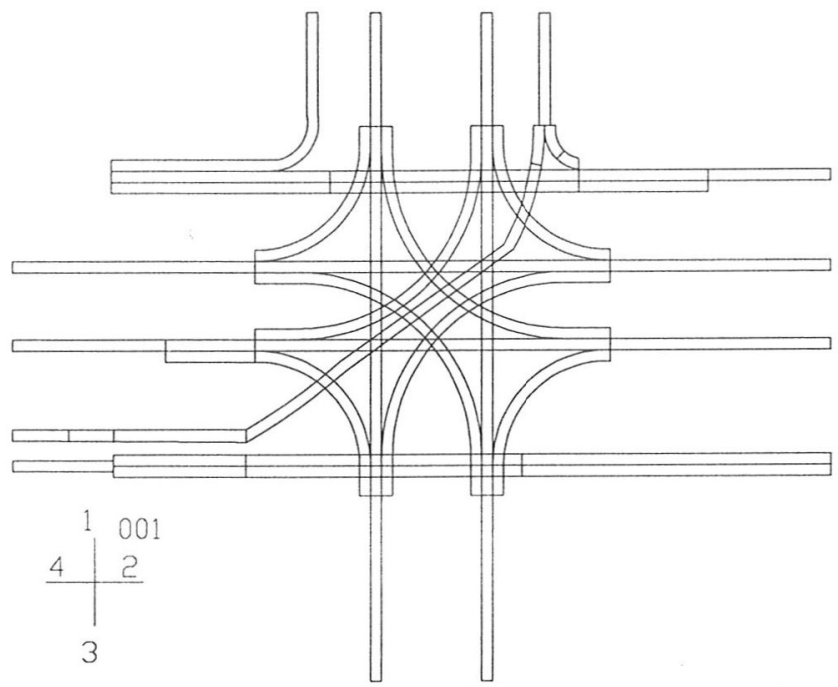

Since the evaluation of optimal intensity can be in most cases done properly by the SOUT macro-model, the use of micro-models for railway traffic is therefore limited to timetable check-ups, precise analysis when traffic intensity is close to optimal, and for atypical cases. The FLEXSYT micro-model was calibrated for railway simulations and used for track allocation [10] and automatic block control simulations, however in most cases the SOUT system gave sufficient results.

\section{PRIORITY AND DETECTION OF TRAMS}

The FLEXSYT system was of multiple use for street traffic quality simulations in Poznań, among them simulations of tram traffic quality on junctions with intelligent traffic management. Simulation done for Most Teatralny - Dąbrowskiego - Roosevelta junction (126 trams per hour, car bypass of an immediate city centre, heavy pedestrian and bicycle traffic) show the dependence between traffic management method and quality. Presented in Table 2 are: right of way (RW - priority on the bypass, no traffic lights), fixed time program (FX), two vehicle actuated programs (VA - with priority to cars), and two traffic responsive programs (TR - with priority for trains, later cars). One of simulation results was disqualification of the VA programs as too harsh for trams and implementation of other programs, with TR-1 as the main operational program. Unfortunately, mistakes made in the implementation process resulted in only partial, but still radical, improvement of tram traffic quality. 
The TR programs were constructed to provide trams with full priority, meaning that trams should pass thejunction freely, unless another tram blocks the way. It is visible, that even with exceptionally high tram traffic intensity, interactions caused by collision of tram tracks have very little (average delay less than a second, maximum delay 18 seconds) influence on tram

Table 2. Average delay of objects and average speed on Most Teatralny - Dąbrowskiego - Rooseveta junction in Poznań [1]. The model covered only the junction, excluding tram stops, located after the junction, and nearby (90 m apart) Poznań Fast Tram outlet

\begin{tabular}{lrrrrrr}
\hline Object type & RW & FX & VA-1 & VA-2 & TR-1 & TR-2 \\
\hline \multicolumn{7}{c}{ Average delay [seconds/object] } \\
\hline Cars & 6.6 & 110.4 & 91.1 & 228.9 & 73.7 & 48.3 \\
Trams & 20.7 & 43.2 & 69.9 & 60.3 & 0.9 & 0.9 \\
Pedestrians & 133.5 & 50.2 & 215.9 & 207.2 & 165.8 & 400.4 \\
\hline \multicolumn{7}{c}{ Average speed [km/h] } \\
\hline Cars & 55.02 & 21.75 & 29.44 & 17.87 & 28.86 & 35.08 \\
Trams & 28.59 & 19.27 & 15.45 & 16.61 & 33.74 & 33.74 \\
Pedestrians & 0.69 & 1.30 & 0.40 & 0.47 & 0.75 & 0.19 \\
\hline
\end{tabular}

traffic quality. Such traffic programme requires however, that all colliding traffic has to be stopped, therefore the tram must be detected appropriately early. The detection should consist of at least two detectors, one located just after the stop line, the second before the stop line at a distance showed by Eq. 5 [4].

$$
L_{2}=V_{\text {proj }} \cdot\left[\max \left(T_{\text {mzi }}+T_{\min \text { zieli }}\right)+T_{h}+T_{r}+T_{b}\right]
$$

where: $L_{2}$ - distance from the stop line to the detector $[\mathrm{m}] ; V_{\text {proj }}$ - speed of trams approaching the junction $[\mathrm{m} / \mathrm{s}] ; T_{m i}$ - intergreen time between signal group $i$ and the tram signal [s]; $T_{\min z i e l i}-$ minimum green for the i signal group (blinking "go" signal included) [s]; $i$ - any signal group in collision with the tram signal; $T_{h}$ - time for tram to decelerate from the approaching speed to halt [s]; $T_{r}$ - tram drivers' reaction time [s]; $T_{b}$ - additional time to leave the junction (for example for road - railway junctions with half - arm gates in Poland minimum 6 seconds) [s].

Other detectors are not necessary, but also welcome, since they allow more precision in the traffic management. Good locations for a third detector are given by Eqs. 6 and 7 . The program should also read the direction the trams want to go (if there is a turnout) and treat each tram separately.

The VA program allows to shorten the distance between the stop line and the second detector, according to Eq. 6,

$$
L_{2}=V_{\text {proj }} \cdot\left[\max \left(T_{\text {mzi }}\right)+T_{h}+T_{r}+T_{b}\right]
$$


or, if at the same time a parallel car stream, not separated from the tram track by an asylum, might receive green light, according to Eq. 7.

$$
L_{2}=V_{\text {proj }} \cdot\left(T_{h}+T_{r}\right)
$$

If the VA program states that the tram signal should fit between two normal phases of the traffic lights program, the distance can be calculated according to Eq. 8 [4], under a condition that all signals of the preceding phase in collision with the tram signal end with that phase.

$$
\begin{gathered}
L_{1}=V_{\mathrm{proj}} \cdot\left[\max _{i}\left(\Delta T_{\mathrm{mzi}}\right)+T_{h}+T_{r}\right] \\
\Delta T_{\mathrm{mzi}}=T_{\mathrm{mzi}}-\underset{j}{\min }\left(T_{\mathrm{mzij}}\right)>0
\end{gathered}
$$

where: $\Delta T_{\mathrm{m} z \mathrm{i}}$ - critical intergreen time difference [s]; $i$ - any signal group in collision with the tram signal for the phase to be finished; $j$ - any signal group in collision with the tram signal for the phase to begin;

If the stop line is preceded by a tram stop, the distance should be shortened by excluding deceleration time and subtracting time spent on the tram stop due to passenger exchange, with half the deceleration time. Equation 5 receives therefore the shape of equation 10 [4], Eqs. 6 and 8 change respectively:

$$
L_{1}=V_{\text {proj }} \cdot\left[\max \left(T_{\text {mzi }}+T_{\text {min zieli }}\right)+T_{r}+T_{b}-T_{p}-\frac{T_{h}}{2}\right]>0
$$

\begin{tabular}{|c|c|c|c|c|}
\hline Objects & $\begin{array}{c}\text { Total distance travelled } \\
{[\text { object } \cdot \mathrm{km} / \mathrm{h}]}\end{array}$ & $\begin{array}{l}\text { Total time spent } \\
{[\text { object } \cdot h / h]}\end{array}$ & $\begin{array}{l}\text { Total delay } \\
{[\text { object } \cdot \mathrm{h} / \mathrm{h}]}\end{array}$ & $\begin{array}{c}\text { Speed } \\
\text { [object/h] }\end{array}$ \\
\hline \multicolumn{5}{|c|}{ Trams only } \\
\hline Trams & 91.35 & 3.32 & 0.25 & 27.50 \\
\hline \multicolumn{5}{|c|}{ Trams + pedestrians; full tram priority } \\
\hline Trams & 86.75 & 3.67 & 0.78 & 24.02 \\
\hline Pedestrians & 1678.19 & 521.36 & 98.28 & 3.24 \\
\hline \multicolumn{5}{|c|}{ Trams prior to cars prior to pedestrians unless non green times exceed 120 seconds } \\
\hline Trams & 86.75 & 3.76 & 0.87 & 23.58 \\
\hline Pedestrians & 1109.50 & 937.74 & 658.44 & 1.30 \\
\hline Cars & 1139.12 & 32.45 & 12.21 & 36.36 \\
\hline
\end{tabular}

where: $\quad T_{p}$ - time spent on the tram stop due to passenger exchange.

Table 3. Simulation results of Most Teatralny - Roosevelta - Dąbrowskiego junction in Poznań. Tram are given full priority, but due to wrong location of detectors other signals decrease tram traffic quality [1]

If $L_{1}$ is equal 0 or negative, the tram stop is for one tram only, and out of service cars such as technical or broken do not require priority, than one detector might be sufficient. Such 
detector should be at a distance from the stop line no longer than the minimum length of a rail car [4]. At tram stops serving two trams at one time two detectors, one just after the stop line and the second just before the stop platform, should be proposed; that way arrival time of the second tram is also known. For the tram stops serving only one tram at a time location of two detectors instead of one should yield slightly better traffic management, in this case however the improvement usually does not justify the expenditure.

The results and equations presented above were acquired from FLEXSYT simulations and verified in practical implementations. The simulations proved their importance when it came to convincing authorities about location of detectors, for full priority 200-300 $\mathrm{m}$ from the stop line. Unfortunately, not always the detectors were located accordingly, resulting in reduction of positive effect. Presented in Table 3 are results of simulations of the Most Teatralny Roosevelta - Dąbrowskiego junction with the Poznań Fast Tram inlet, including tram stops and mistakes in detector locations. These inconveniencies do not influence tram traffic quality in absence of other junction users, inclusion of these users results however in over three - fold tram delay increase. This example shows clearly sensitivity of intelligent traffic management and a need for control of infrastructure layout. Computer simulations can be used for such check-ups, as well as to convince authorities. Experience gained in construction of intelligent traffic management shows also a need for investigations after implementations, comparing and contrasting reality with expected results, usually acquired from computer simulations.

\section{TRAFFIC LIGHT COORDINATION FOR TRAMS}

The FLEXSYT system allows for simulations of several junctions, enabling therefore investigations of traffic lights coordination. Results of such simulations for Most Teatralny Roosevelta - Dąbrowskiego junction are given in Table 4. Contrasted are results with random incoming of vehicles and with vehicles from the north (cars and trams) and east (trams only) coming in coordination. Such coordination results from traffic management program on the neighbouring junctions giving trams only limited priority or treats them as other users. The simulation results show that proper coordination of programs between these junctions can improve (or in case of improper coordination - decrease) traffic quality on the investigated junction.

Table 4. Traffic quality on Most Teatralny - Roosevelta - Dąbrowskiego junction in Poznań with Poznań Fast Tram inlet resulting from coordination with neighbouring junctions [1]

\begin{tabular}{|c|c|c|c|c|c|c|}
\hline \multirow{2}{*}{$\begin{array}{l}\text { Junction } \\
\text { user }\end{array}$} & \multicolumn{3}{|c|}{ Random arrival of vehicles } & \multicolumn{3}{|c|}{ Vehicles from north and east in coordination } \\
\hline & $\begin{array}{c}\text { Total delay } \\
{[\text { obj } \cdot h / h]}\end{array}$ & $\begin{array}{c}\text { Average delay } \\
{[\mathrm{s} / \mathrm{obj}]}\end{array}$ & $\begin{array}{c}\text { Average speed } \\
{[\mathrm{km} / \mathrm{h}]}\end{array}$ & $\begin{array}{l}\text { Total delay } \\
{[\mathrm{obj} \cdot \mathrm{h} / \mathrm{h}]}\end{array}$ & $\begin{array}{c}\text { Average delay } \\
{[\mathrm{s} / \mathrm{obj}]}\end{array}$ & $\begin{array}{c}\text { Average speed } \\
{[\mathrm{km} / \mathrm{h}]}\end{array}$ \\
\hline Car & 126.01 & 222.4 & 18.74 & 77.81 & 137.4 & 27.24 \\
\hline Tram & 0.99 & 28.3 & 24.75 & 0.78 & 22.3 & 25.76 \\
\hline Pedestrian & 329.22 & 139.4 & 1.30 & 261.16 & 110.6 & 1.71 \\
\hline
\end{tabular}


Table 5. Simulation results of tram - car coordination on Głogowska street. (T) states a traffic light just after a tram stop: Peds. signals a pedestrian crossing managed by traffic lights [3]

\begin{tabular}{|c|c|c|c|c|c|c|c|c|}
\hline & \multicolumn{4}{|c|}{ Trams } & \multicolumn{4}{|c|}{ Cars } \\
\hline & \multicolumn{2}{|c|}{ cycle 90 seconds } & \multicolumn{2}{|c|}{ cycle 120 seconds } & \multicolumn{2}{|c|}{ cycle 90 seconds } & \multicolumn{2}{|c|}{ cycle 120 seconds } \\
\hline & $\begin{array}{c}\text { Average } \\
\text { delay } \\
{[\mathrm{s}]}\end{array}$ & $\begin{array}{c}\text { Max. } \\
\text { delay } \\
{[\mathrm{s}]}\end{array}$ & $\begin{array}{c}\text { Average } \\
\text { delay } \\
{[\mathrm{s}]}\end{array}$ & $\begin{array}{c}\text { Max. } \\
\text { delay } \\
{[\mathrm{s}]}\end{array}$ & $\begin{array}{c}\text { Average } \\
\text { delay } \\
{[\mathrm{s}]}\end{array}$ & $\begin{array}{c}\text { Max. } \\
\text { delay } \\
{[\mathrm{s}]}\end{array}$ & $\begin{array}{c}\text { Average } \\
\text { delay } \\
{[\mathrm{s}]}\end{array}$ & $\begin{array}{c}\text { Max. } \\
\text { delay } \\
{[\mathrm{s}]}\end{array}$ \\
\hline \multicolumn{9}{|c|}{ Towards Górczyn } \\
\hline Hetmańska (T) & 46.6 & 95 & 65.7 & 205 & 26.0 & 104 & 80.8 & 506 \\
\hline Depot & 2.4 & 3 & 2.3 & 3 & & & & \\
\hline left into Depot & 2.3 & 2 & 2.6 & 3 & & & & \\
\hline Peds. - Palacza & & & & & 14.8 & 172 & 347.0 & 963 \\
\hline Palacza (T) & 7.6 & 15 & 8.8 & 19 & 6.8 & 164 & 25.1 & 224 \\
\hline Górczyńska & 3.8 & 8 & 3.9 & 6 & 6.4 & 15 & 8.1 & 87 \\
\hline Kosynierska & 0.0 & 0 & 0.1 & 3 & 1.4 & 60 & 1.8 & 81 \\
\hline Sielska & 0.3 & 4 & 0.8 & 6 & 3.6 & 71 & 1.9 & 39 \\
\hline Krzywa & 14.7 & 82 & 15.2 & 22 & 31.3 & 97 & 10.0 & 90 \\
\hline \multicolumn{9}{|c|}{ Towards Centre } \\
\hline Krzywa & 56.0 & 95 & 39.6 & 80 & 32.3 & 109 & 47.1 & 109 \\
\hline Peds. - Sielska & & & & & 53.9 & 107 & 40.3 & 128 \\
\hline Sielska $(\mathrm{T})$ & 16.8 & 27 & 8.8 & 18 & 13.8 & 80 & 13.7 & 97 \\
\hline Kosynierska & 4.9 & 6 & 4.9 & 6 & 3.9 & 67 & 3.9 & 82 \\
\hline Górczyńska & 0.0 & 0 & 0.3 & 5 & 3.5 & 66 & 2.4 & 81 \\
\hline Peds. - Palacza & & & & & 14.4 & 74 & 16.4 & 89 \\
\hline Palacza $(\mathrm{T})$ & 7.6 & 12 & 7.8 & 12 & 3.1 & 30 & 2.8 & 113 \\
\hline Depot & 3.5 & 6 & 3.6 & 6 & 1.5 & 39 & 1.1 & 10 \\
\hline Hetmańska & 3.9 & 9 & 12.2 & 23 & 51.2 & 130 & 16.0 & 99 \\
\hline \multicolumn{9}{|c|}{ Side streets } \\
\hline & \multicolumn{4}{|c|}{ Arrival from the west } & \multicolumn{4}{|c|}{ Arrival from the east } \\
\hline Palacza & 107.6 & 316 & 54.9 & 186 & 72.5 & 316 & 56.6 & 118 \\
\hline Górczyńska & 48.4 & 102 & 33.3 & 112 & 45.6 & 129 & 31.9 & 108 \\
\hline Kosynierska & 33.1 & 91 & 28.1 & 112 & 39.3 & 95 & 35.3 & 113 \\
\hline Sielska & 40.7 & 83 & 45.0 & 110 & 43.6 & 78 & 59.8 & 109 \\
\hline
\end{tabular}

Simulations using the FLEXSYT system enabled investigations of linear car - tram coordination. The coordination was tested on Głogowska street in Poznań, on a stretch between two major junctions - with Hetmańska street and with Krzywa street [3]. These junctions served as "gates", on which the coordination was to be spread. In other words, these junctions had perpendicular traffic of such intensity (Hetmańska street had also a tram line), that trams and cars on Głogowska street could receive "go" light only at certain time in a traffic program cycle. The junctions between these "gates", all managed by traffic lights, had minor traffic, except for Palacza street. At first trams were supposed to receive full priority 
and cars - guaranteed green light within specified "windows" designed to provide coordination. Simulation results showed, that fast trams had to wait at the exit "gates", therefore it was decided to use tram stops just before traffic lights to reduce travel time dispersion.

Simulation results, presented in Table 5 show that the good, but not ideal, coordination was possible to achieve. Trams have significant delays only at entry "gates", with regularisation done at tram stops and at Krzywa street exit. Cars have bigger delays, however small enough to conclude that, apart from the "gate" and the next junction after the "gate" (heavy turns at the "gates"), the coordination is appropriate. Delays at streets crossing Głogowska street are generally smaller that half the cycle time, therefore the service is also proper. The maximum delay longer than the cycle time, resulting from tram - car coordination: a tram going at a time the cars were not - was acceptable due to small intensity of traffic. One exception was Palacza street - here the traffic intensity was high enough to expand waiting time above cycle time. A proposal was therefore stated to modify traffic management on that junction, unfortunately final decisions have already been made. In the outcome car coordination is disturbed.

Due to their length and low acceleration, trams produce high intergreen times after their signal. If they are parallel to a car inlet with low intensity, the tram signal may be in the signal chain decisive to the cycle length. In such situations trams optimal traffic management requires precision in tram service, the role of the tram for city transport requires, on the other hand, priority. Simulations done for Św. Marcin street in Poznań dealt with such case.

The critical junction with Niepodległości street was preceded by two junctions with traffic lights, just before the latter (Gwarna street junction) a tram stop was located. The tram stop served as a gate for the trams, which were sent by a 5 second long signal, then crossed the second junction and the junction with Niepodległości street without stopping, although having only 5 second long "go" signals. Such coordination was possible because the tram did not stop. After computer simulations this program was installed and proved its quality. In the course of installation, when only the Gwarna street junction operated according to an old program, it could be observed that a tram that had to stop at the middle junction had to stop also at Niepodległości junction, however all trams that went smoothly through the second junction also travelled freely through the Niepodległości junction [2].

\section{NEW TRAFFIC EVALUATION PROBLEMS}

Improvement in transport technology requires traffic analysis programs to be updated. Construction of controllers able to manage traffic with variable cycle times, and later with acyclic traffic responsive programs, prompted a small revolution in traffic simulation programs. The FLEXSYT system was one of the first to enable simulations of a wide scope of intelligent traffic management programs, not being however fully compatible with controller programs. 
Currently improvements in rail traffic simulators should take into account tram - train systems, including possibility of driving at sight distance with other trains being managed traditionally, with shortness and good acceleration parameters of the tram - train cars. The idea of European Train Control System (ETCS) with its third level allowing travel at braking distance would require new simulation programs. Traffic models for these programs, such as moving buffer model [13], would have to be use experience from both car and train traffic analysis.

The FLEXSYT model simulates tram traffic analysing each tram at a time. The model is based on a car traffic model taking into account possible very low intensity; as a result tram track capacity in the FLEXSYT model is higher than theoretical capacity. A question might be asked about the influence of such errors on traffic quality analysis, especially when they are focused on rail traffic, instead of the rail traffic being just an appendix to the cars.

\section{CONCLUSIONS}

- Computer simulations of simple transport knots enable cheaper and less time consuming design; investigations of complex transport knots require the simulations to obtain credible results.

- The SOUT and FLEXSYT systems proved to be a useful tool for rail traffic quality evaluation.

- Optimal design of transport infrastructure aimed at capacity maximisation requires best traffic management devices to be used on critical knots. Usually use of lesser traffic management devices on track stretches between knots does not reduce capacity of such rail network.

- Capacity reserves in transport might be found also in proper track allocation and minimisation of track collisions.

- Rail traffic quality should be checked for given peak periods. On low intensity lines one must take into account influence of long headways on research results.

- Intelligent traffic management gives greater possibilities: for improving traffic quality, but also for making mistakes. Computer simulation is a useful tool for low cost investigations enabling proper design.

- Simulations of traffic quality should be made for junction geometry accepted by authorities, but with a possibility to make improvements of geometry and traffic management.

- Installation of intelligent traffic lights on complex junctions should include simulation of traffic quality with comparison and contrast between expected and acquired results. The investment process should take into account possible corrections after the check-up phase.

- Intelligent traffic lights can handle high intensity of tram traffic. Full tram priority can reduce tram delay but to a second, on the condition of proper traffic lights program and detector location and quality. Free tram travel with proper coordination can greatly reduce dispersion of travel time, enabling therefore precise tram management on critical junctions. 
- Intelligent traffic management includes coordination between junctions. Proper coordination can give better results than optimal program on an autonomous junction. In tram coordination it is recommended to decrease travel time dispersion on tram stops.

\section{References}

[1] M. Kaczmarek. A. Krych. J. Rychlewski. Multi-objective evaluation of traffic at complex intersection with different control strategies. Proceedings of International Conference on Modelling and Management in Transport Poznań-Kraków. 2. 17-22 (1999).

[2] M. Kaczmarek. J. Rychlewski. Sterowanie ruchem $w$ centrum Poznania. Proceedings of III Conference Problemy komunikacyjne miast $w$ warunkach zattoczenia motoryzacyjnego. Poznań. 217-228 (2001).

[3] M. Kaczmarek. J. Rychlewski, Sterowanie skoordynowane ruchem $z$ priorytetem dla tramwajów. Proceedings of International Conference Nowoczesne rozwiazania techniczne $w$ komunikacji tramwajowej. Wroclaw. 131-138 (2000).

[4] M. Kaczmarek. J. Rychlewski. Zmiennoczasowa sygnalizacja świetlna na skrzyżowaniach

[5] A. Krych. J. Rychlewski. Rozwiazania tramperowe $w$ aglomeracji poznańskiej - idea,. studia $i$ problemy aplikacji. Proceedings of Conference Zintegrowany system miejskiego transportu szynowego. Wroclaw. 67-76 (2003).

[6] W. Ratajczak. Modelowanie sieci transportowych. Wydawnictwo Naukowe UAM. Poznań 1999.

[7] J. Rychlewski. Badanie optymalnej intensywności ruchu kolejowego na odcinku Poznań Główny Poznań Wschód za pomoca systemu SOUT. Proceedings of II Conference Problemy komunikacyjne miast $w$ warunkach zatłoczenia motoryzacyjnego. Poznań. 202-209 (1999).

[8] J. Rychlewski. Drogi optymalne $w$ sieci kolejowej $z$ zamknięciami torów. Doctoral Thesis presented at Poznań University of Technology. Poznań 2001.

[9] J. Rychlewski. Możliwości i problemy wykorzystania rezerw przepustowości sieci kolejowej do obstugi komunikacyjnej aglomeracji poznańskiej. Proceedings of IV Conference Problemy komunikacyjne miast w warunkach zatłoczenia motoryzacyjnego. Poznań. 213-222 (2003).

[10] J. Rychlewski. Simulation of passenger rail interchange using SOUT and FLEXSYT systems. Proceedinas of $10^{\text {th }}$ Into rnational Scientific Conference Communications on the Edge of the Millenniums. Žilina. 151-154 (1998).

[11] W. Rydzkowski. K. Wojewódzka-Król. Współczesne problemy polityki transportowej. Polskie Wydawnictwo Ekonomiczne. Warszawa 1997.

[12] P. A. Steenbrink. Optimization of Transport Networks. John Wiley \& Sons. London. New York. Sydney, Toronto 1974.

[13] J. Węgierski. Metody probabilistlyczne $\quad w$ projektowaniu transportu szynowego. WkiŁ. Warszawa 1971.

[14] J. Woch. Complex railway junctions capacities and railway network effectiveness. Archives of Transport. 13/3. 87-108 (2001).

[15] J. Woch. Kształtowanie płynności ruchu w gęstych sieciach transportowych. Szumacher. Kielce 1998.

[16] J. Woch. Narzędzia analizy efektywności $i$ optymalizacji sieci kolejowej. Wydawnictwo Politechniki Śląskiej. Gliwice 2001.

[17] J. Woch. Ogólne ujęcie przepustowościjako problemu wymiarowania układów kolejowych. Ed.: A. Truskolaski and J. Węgierski, Informatyka $w$ planowaniu technicznym przewozów kolejowych. WkiŁ. Warszawa 1977. 